\title{
Performance of geothermal power plants (single, dual, and binary) to compensate for LHC-CERN power consumption: comparative study
}

\author{
M. El Haj Assad ${ }^{1 *}$, E. Bani-Hani ${ }^{2}$ and M. Khalil ${ }^{1}$
}

${ }^{*}$ Correspondence: massad@sharjah.ac.ae 'SREE Department, University of Sharjah, P O Box 27272, Sharjah, United Arab Emirates

Full list of author information is available at the end of the article

\begin{abstract}
The aim of this study is to compare between single flash, dual flash, and binary power plants in terms of the power generated, their performance, and the related cost. The results from the comparison are used to find the best plant type that can be implemented to compensate for the very high power requirements of a large hadron collider (LHC). Using the setting and requirements of the CERN LHC in Geneva, Switzerland, the study uses System Advisor Model software to analyze the implementation of the different plant types. Results show that the binary power plant has the best performance and lowest cost compared with other geothermal power plants analyzed, and there is a reduction in the total power generation cost when using renewable energy sources.
\end{abstract}

Keywords: Geothermal power plants, System Advisor Model, Power factor, Energy cost

\section{Background}

During the past few years, great attention has been paid to the use of waste heat and renewable energy due to their contribution towards reducing the reliance on fossil fuels. Moreover, there is a great demand for energy worldwide (Sheng et al. 2013). Renewable energy is becoming an important source of energy for the industry. The use of renewable energy does not contribute to gas emissions that harm the environment at the same level as emissions from fossil fuels. One of the most readily available renewable energy sources is geothermal energy which is stored within the Earth all over the globe at varying depths according to location.

This new source of available energy is environmentally safe as it has fewer harmful effects than traditional energy sources that rely on fossil fuels (Lurque et al. 2008; McKendry 2002). The depletion of the fossil fuel reserves calls for more sources of sustainable energies such as geothermal, wind, solar, and tidal energy. As a result of this need, a new device for tidal energy conversion was tested (El Haj Assad et al. 2016).

The conversion of geothermal energy into electrical energy is neither a cheap nor a simple process so there is a real need to use the available energy in an efficient way. As of today, there are three different types of geothermal power plants which are (1) the flash 
steam, (2) the dry steam, and (3) the binary ORC (Organic Rankine Cycle) geothermal power plant (DiPippo 2007). Building these power plants depends on the geothermal resources which are classified accordingly as having low enthalpy, medium enthalpy, or high enthalpy (Dickson and Fanelli 2003).

In dry steam reservoirs, the dry steam is obtained by digging wells that are 700010,000 feet deep, after which the steam is transported through pipe from the well to the turbine generator in order to generate electricity. Moreover, the condensed water from the turbine can be used to cool the power plants. Using dry steam reservoirs is an efficient and successful way of generating electricity, but it is rarely used. As for hot water reservoirs, the hot water from the wells is connected to one, two, or more separators to convert the water into steam. This steam then flows through pipes towards the turbine to produce electricity, after which the steam is condensed and used to cool the power plant system. This type is more common than the previously described dry steam reservoirs.

In a single flash steam power plant, the geothermal fluid is in liquid state (Ameri et al. 2006) which is expanded through an expansion valve resulting in two-phase flow. This mixture of liquid and vapor is directed to a separator kept at a constant temperature and pressure, so that the liquid and the vapor are separated from each other. The produced vapor is directed to the steam turbine to generate electricity while the remaining liquid is re-injected to a re-injection well.

The double flash steam power plant has the same working principles as the single flash power plant except that in the former, two separators are used which result in both high- and low-pressure steam flows that run the steam turbine. Double flash geothermal power plants produce a higher power output than single flash geothermal power plants but at a higher cost. The cost of the dual flash is higher than the single flash due to the use of more piping, a second separator, and low- and high-pressure steam turbines. To compensate for the high cost of a double flash power plant, an exergy analysis has been used as an effective tool to maximize the power output and hence improve the efficiency of the double flash power plant (Ameri et al. 2011; Pambudi et al. 2013).

In a binary geothermal power plant (ORC), the hot geothermal fluid is directed to a heat exchanger (vaporizer) where a secondary fluid of low boiling point and high vapor pressure circulates. The heat exchange process between the geothermal fluid and the secondary fluid causes the secondary fluid to vaporize and this generated vapor is then used to run the turbine in order to produce electricity. A flash steam power plant produces about $27 \mathrm{~kg} / \mathrm{MWh} \mathrm{CO}_{2}$ emissions while the ORC power plant produces zero $\mathrm{CO}_{2}$ emissions (Kagel et al. 2007). The beauty of the geothermal power plant is that it requires about $160 \mathrm{~m}^{2} / \mathrm{GWh}$ land usage which is a very small area when compared to other conventional and renewable power plants (Tester 2006).

Due to the importance of ORC, recently many investigations have been conducted to evaluate the performance of the ORC power plant by using different mixtures of the secondary fluid in the Rankine cycle part of the geothermal power plant (Bao and Zhao 2013; Garg et al. 2013; Yang et al. 2013).

Recently, second law analysis has been applied to evaluate the thermal performance of a suggested ORC-OFC combined geothermal power plant (Jianyong et al. 2015), which showed that the performance of the ORC-OFC combined power plant is much higher than the performance of ORC and OFC power plants operated separately. A second law 
analysis of combined Flash-ORC power plant has been applied to determine the power output and the efficiency of the power plant (Gong et al. 2010).

Negawo (2016) reviewed some geomaterial aspects of geothermal energy to show and discuss the role of geomaterials on the utilization of geothermal energy. This research focuses on analyzing the geothermal energy power plants to improve their performance and increase the dependency on renewable energy sources where geothermal energy represents $2 \%$ of the total renewable energy resources (Pazheri et al. 2014). Modeling of these systems helps in anticipating the amount of power generated and the cost as a function of geothermal system parameters such as temperature, depth, and pressure along with many other parameters. In this study, the so-called System Advisor Model (SAM) software was used.

This study was carried out based on the built-in location parameters for Geneva in Switzerland (Vuataz 2008) at a time when countries such as Pakistan (Younas et al. 2016) and Ethiopia (Teklemariam et al. 2000) have started relying on geothermal energy. The geothermal source available under the ground of Geneva is hydrothermal resource. Hydrothermal resources mean that the fluid can be in vapor form as found in steam reservoirs or it can be at a high temperature as found in deep underground hot water which keeps the surface that comes in contact with it constantly hot. There are different ways to use hydrothermal resources depending on the temperature of the fluid and its depth. If the temperature of the hydrothermal resource is low, it can be used directly to heat buildings or warm swimming pools in addition to other similar uses. Such use of hydrothermal resources is referred to as direct use. On the other hand, if the temperature of the hydrothermal resource is high, it may be used to produce electricity (Yari 2010). Two types of hydrothermal resources that can be used to produce electricity are (1) a vapor form source (known as dry steam reservoirs), and (2) a liquid form source (known as hot water reservoirs).

\section{Geothermal power plants}

Geothermal power plants mainly come in two groups, namely, steam and binary power cycles. These cycles operate at high geothermal fluid enthalpy. The single flash cycle contains only one throttling valve (expansion valve) through which the geothermal fluid is expanded, and one separator to separate the vapor from the liquid after the expansion process in the expansion valve. This separation occurs at constant pressure and temperature. The vapor generated is sent to a steam turbine to produce electricity while the liquid is re-injected back to the ground. The geothermal fluid in the well is above $182{ }^{\circ} \mathrm{C}$ for the flash steam power plants. Flash steam power plants use a condenser to condense the steam leaving the turbine and then re-inject it into the ground.

Binary cycles (ORC) are usually implemented when the geothermal fluid has low enthalpy but with new chemical technology that allow the development of new mixtures of working fluids, ORC may operate at temperatures up to $200{ }^{\circ} \mathrm{C}$. The benefit of such a power plant is that the geothermal fluid is circulated in a closed loop so as not to produce any harm to the environment. However, this cycle needs a secondary fluid which is heated by the geothermal fluid in the heat exchanger (vaporizer) where it eventually vaporizes following which it gets sent to the turbine for electricity production. 


\section{Single flash steam power plant}

Figure 1 shows the schematic diagram of the single flash steam power plant. The use of a flash system results in the elimination of a large portion of energy in brine (liquid) form from the separator due to the low steam quality that emanates from the two-phase fluid following the expansion valve. Single flash power plants are usually considered as the most economical alternative for available geothermal resources temperature above $190{ }^{\circ} \mathrm{C}$. Higher temperature resources will produce more liquid and steam for natural pressure conditions. For high-temperature resources where two phase is dominated, the geothermal fluid is moved to the surface of the borehole as a mixture of steam and liquid (brine). The separation process of steam from brine occurs either in a horizontal separator under gravitational effect or in a vertical separator under cyclonic motion. Following this the steam is directed to the steam turbine while the saturated liquid is used as a heat input source for ORC in a combined flash-ORC power plant (Gong et al. 2010) or, alternatively, the steam gets re-injected to the reservoir through re-injection well.

Single flash power plants are classified according to their steam turbines types, i.e., the turbine exit conditions. Two such basic types are the single flash with a condensation system and the single flash back pressure system. In the first type, a condenser operating at very low pressure is used to condensate the steam leaving the steam turbine. The condenser should operate at low vacuum pressure to maintain a large enthalpy difference across the expansion process of the steam turbine, hence resulting in a higher power output. The geothermal fluid usually contains non-condensable gases which are collected at the condenser. Such a collection of gases may raise the condenser pressure,

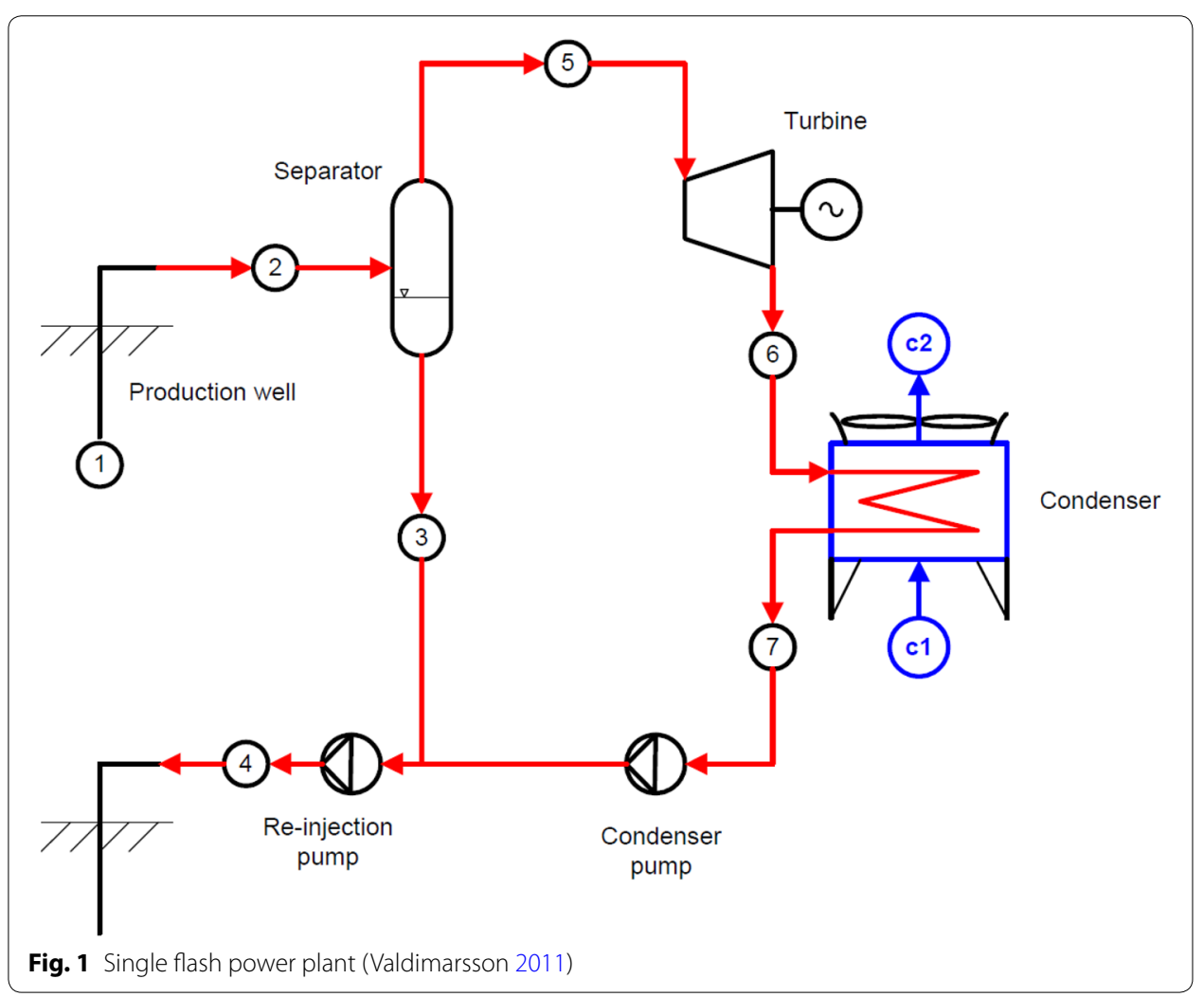


therefore the gases should be removed from the condenser. This can be achieved by installing vacuum pumps, compressors, or steam ejectors. The condenser heat removal is done either by using a cooling tower or through cold air circulation in the condenser.

The condensate forms a small fraction of the cooling water circuit, a large portion of which is then evaporated and dispersed into the atmosphere by the cooling tower. The cooling water surplus (blow down) is disposed of in shallow injection wells. In single flash condensation system, the condensate does have direct contact with the cooling water.

\section{Dual flash steam power plant}

The dual flash steam plant (double flash) is preferred over the single flash steam power plant depending on the conditions of the resource. In fact, it is similar to the single flash power plant except that it produces more steam due to the use of two separators. The schematic diagram of a dual flash power plant is shown in Fig. 2. Using two separators leads to the use of a two-stage steam turbine, whereby one stage operates at high pressure and the other at low pressure. Dual flash power plants are able to produce up to 15-25\% more power than a single flash power plant as their power production capacity is in the range of $4.7 \mathrm{MW}-110 \mathrm{MW}$. In a dual flash power plant, the saturated liquid leaving the first separator is directed to a second separator at lower pressure, resulting in more steam production.

Following the steam production at high and low pressures, all steam gets directed to a steam turbine using separate pipelines. The steam turbine can be a dual admission turbine, a separate turbine, or may be made up of two separate tandem compound turbines

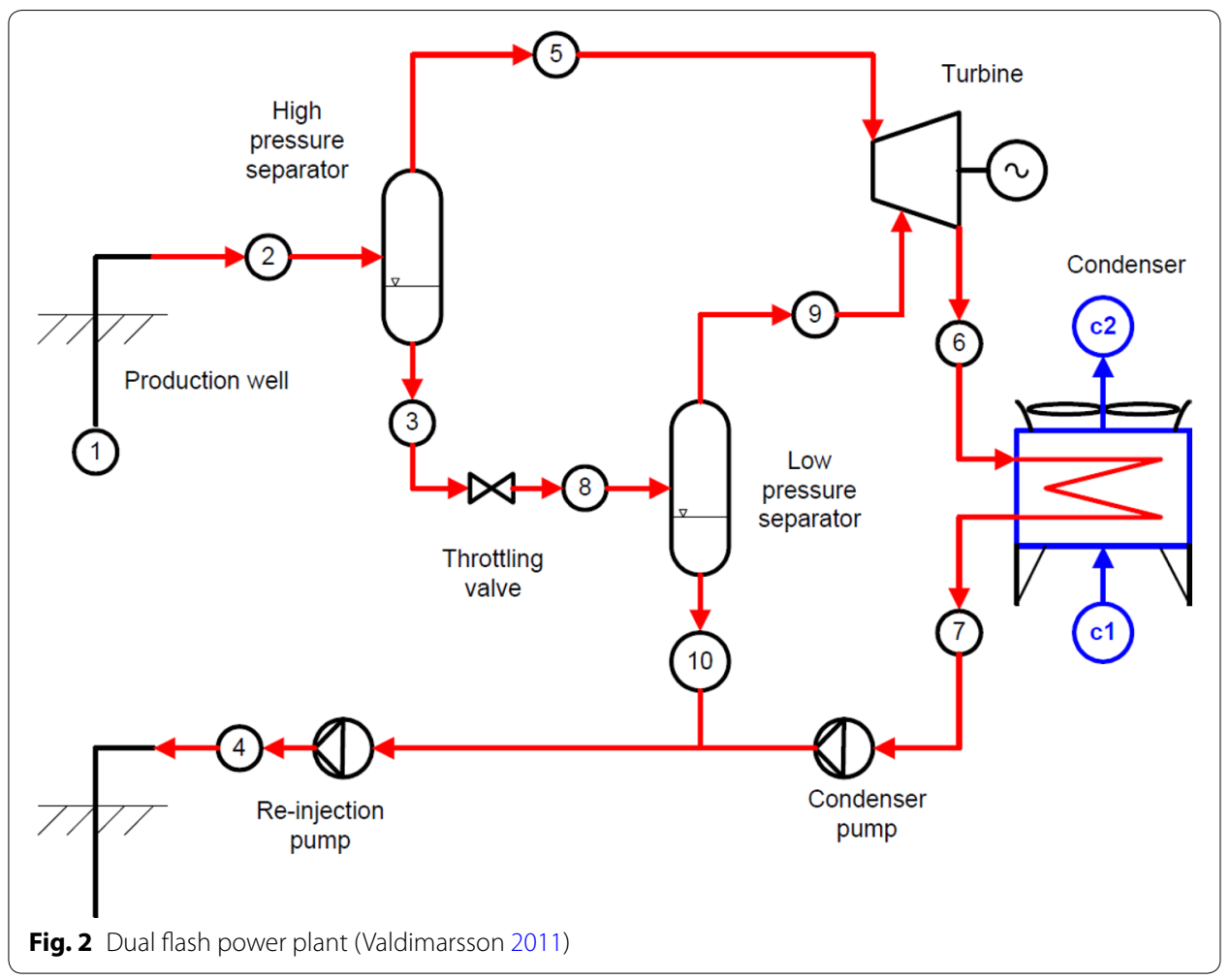


which operate based on the steam inlet pressure. The components of a dual flash power plant are similar to those of a single flash steam power plant. The mineral content of the water becomes concentrated depending on how the dual flash is designed, hence the resource conditions are of extreme importance.

\section{Binary power plant}

In this type of power plant, a secondary fluid such as hydrocarbon or fluorocarbon is used instead of water to run the ORC turbine. In ORC, the geothermal fluid is circulated in a vaporizer and sent back to the re-injection well. The secondary fluid is heated and vaporized in the vaporizer by the heat exchange between the geothermal fluid and the secondary fluid. The generated vapor from the secondary fluid is directed to the turbine for electricity production. The vapor leaving the turbine passes through a regenerator where the superheated steam is used to heat the condensed fluid leaving the condenser before it enters the vaporizer. The schematic diagram of ORC power plant is shown in Fig. 3.

It is possible to run an ORC geothermal power plant using a geothermal fluid having a temperature of $200{ }^{\circ} \mathrm{C}$ through the use of different secondary working fluids such as R600a/R161 (Redko et al. 2016). Such working fluids can operate under temperatures of

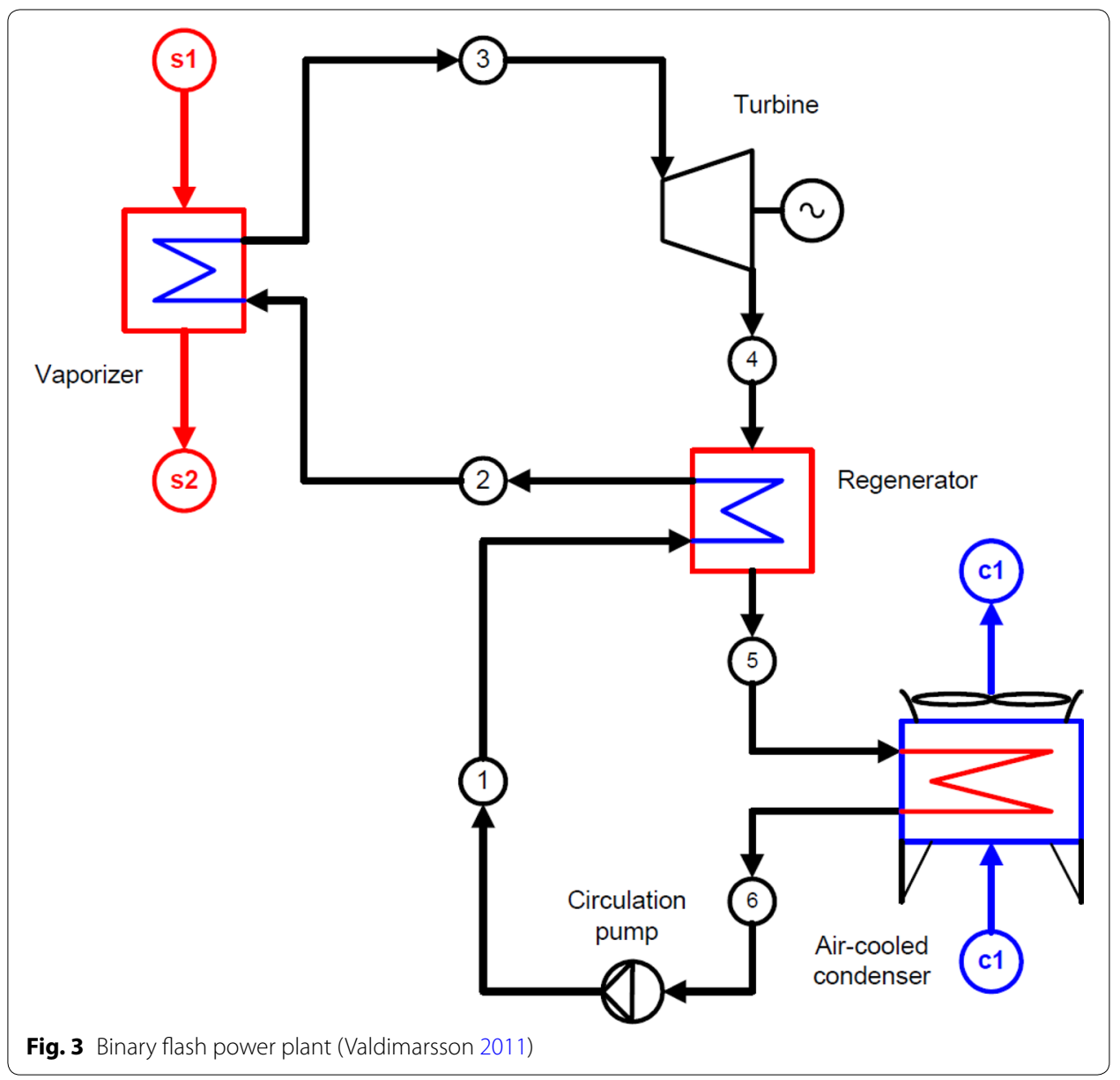


up to $200{ }^{\circ} \mathrm{C}$. Moreover, numerical calculations to obtain the output power of an ORC geothermal power plant were conducted at a geothermal fluid temperature of $200{ }^{\circ} \mathrm{C}$ (Valdimarsson 2011), where Isopentane was used as the secondary working fluid to run the turbine. A binary power plant has several advantages such as reservoir sustainability, high reliability operation, and environmental friendliness. In our study, we used Isopentane as the secondary working fluid.

The main advantages of ORC are that it operates at a low temperature which results in low-mechanical stresses on the turbine, along with the fact that there is no erosion of the turbine blades due to the absence of moisture during the vapor expansion in the turbine. Moreover, the turbine in ORC has a smaller size so it is consequently less expensive, and there are no air in-leakage problems nor problems due to operating in a vacuum, since a vacuum is not needed (DiPippo 1980).

\section{Modeling approach}

The System Advisor Model (SAM) is one of the most sophisticated computer software used in renewable energy technologies developed by the National Renewable Energy Laboratory (NREL) to predict renewable energy system performance and energy cost. It is a software that can be used by engineers, researchers, and project managers alike who are involved in the renewable energy industry. The SAM software does an hour by hour calculation for a whole year $(8760 \mathrm{~h})$ for electric power that is produced by the power plant. Moreover, SAM estimates the energy cost of the geothermal power plant project based on the results obtained from the performance model over the whole project life-cycle.

Operating costs, installation, and system design parameters specified by the user are used as input parameters for SAM in order to estimate the performance and energy costs. These calculations are performed using a detailed performance model and a detailed cash flow. The SAM computation procedure can be summarized through the following order of steps:

1. Use of weather data

2. System specifications

3. Energy production

4. Cost data

5. Utility data and incentives

6. Financial options

7. Annual, monthly, and hourly electric power output, LCOE (levelized cost of energy), revenue, and power factor.

Steps 1 and 2 are used to obtain the energy production. Using steps 3, 4, 5, and 6, SAM estimates the parameters of step 7.

Detailed procedure on how the System Advisor Model works is given in the SAM Help which can be found online.

SAM is used to analyze different types of geothermal power plants. The comparison is set to the following criteria for input conditions: the type of geothermal source is hydrothermal geothermal source, the type of geothermal power plants will be single flash, dual 
flash, and binary geothermal power plants. The location and well parameters are shown in Tables 1 and 2, respectively.

The mathematical model cannot be extracted from SAM. Moreover, it is a very complicated model (SAM Help 2015). All that are needed for the model are the input parameters presented in Tables 1, 2, 3, and 4. The location of the well is presented in Table 1.

Table 2 shows the well parameters such as pump efficiency, pressure, mass flow rate, soil permeability, well height, depth, and many other parameters. The working fluid used in this study is Isopentane. No other parameters are required for the performance model of SAM.

The surrounding conditions such as the ambient temperature and humidity are important in analyzing the power production. Figures 4, 5, 6 show the distribution of weather conditions over the whole year.

Table 3 presents the user input dialog box to estimate the number of wells needed to estimate the plant capital cost which includes confirmation, exploration, production, injection, surface equipment, and installation. The cost due to pumping is also given in Table 3. Pump costs are estimated based on the depth and size of the pump.

Table 4 presents the dialog box for the cost input of the financial model. The table shows the total installed cost which is obtained by summing up the total direct and indirect capital costs specified by the user. The indirect capital cost consists of three different costs (presented as a percentage of the direct cost) as given in the table.

\section{Results and discussion}

\section{Single flash steam power plant}

For a single flash power plant, Fig. 7 shows that the annual contribution to the total power demand cannot exceed $80 \%$ due the efficiency of the power plant and geothermal

Table 1 Location information for the simulation

\begin{tabular}{|c|c|c|c|c|c|}
\hline City & Geneva & Time zone & GMT 1 & Latitude & $46.25^{\circ} \mathrm{N}$ \\
\hline State & $\mathrm{CHE}$ & Elevation & $416 \mathrm{~m}$ & Longitude & $6.13^{\circ} \mathrm{N}$ \\
\hline Country & Switzerland & Data source & 1 WEC & Station ID & 067000 \\
\hline
\end{tabular}

Table 2 Well parameters for the simulation

\begin{tabular}{|c|c|c|c|}
\hline Width & $500 \mathrm{~m}$ & Fracture aperture & $0.0004 \mathrm{~m}$ \\
\hline Height & $100 \mathrm{~m}$ & Number of fractions & 6 \\
\hline Permeability & 0.05 Darcy units & Fracture width & $175 \mathrm{~m}$ \\
\hline $\begin{array}{l}\text { Distance from injection to pro- } \\
\text { duction wells }\end{array}$ & $1500 \mathrm{~m}$ & Fracture angle & $15^{\circ}$ from horizontal \\
\hline Subsurface water loss & $2 \%$ of water injected & Pressure change across reservoir & 65.61217 bar \\
\hline Total resource potential & $210 \mathrm{MW}$ & Average reservoir temperature & $200^{\circ} \mathrm{C}$ \\
\hline Resource temperature & $200^{\circ} \mathrm{C}$ & $\begin{array}{l}\text { Production well bottom hole } \\
\text { pressure }\end{array}$ & $115.208 \mathrm{bar}$ \\
\hline Resource depth & $200 \mathrm{~m}$ & Production well flow rate & $70 \mathrm{~kg} / \mathrm{s}$ \\
\hline Pump depth & $2859.93 \mathrm{ft}$ & Pump efficiency & $60 \%$ \\
\hline Pump work & $5.35728 \mathrm{MW}$ & Pump size & $1345.62 \mathrm{hp}$ \\
\hline $\begin{array}{l}\text { Pressure difference across surface } \\
\text { equipment }\end{array}$ & 25 psi & Excess pressure at pump suction & 50.76 psi \\
\hline Production well diameter & $10 \mathrm{in.}$ & Production pump casing size & 9.625 psi \\
\hline Injection well diameter & $10 \mathrm{in}$. & Specified pump work & 0 \\
\hline
\end{tabular}


Table 3 Configuration specification dialog for the geothermal well

\begin{tabular}{|c|c|c|c|c|c|c|c|c|c|c|}
\hline $\begin{array}{l}\text { Total produc- } \\
\text { tion wells } \\
\text { required }\end{array}$ & $\begin{array}{l}\% \text { of confirr } \\
\text { tion wells u } \\
\text { for product }\end{array}$ & & $\begin{array}{l}\text { Number of } c \\
\text { firmation we }\end{array}$ & $\begin{array}{l}\text { con- } \\
\text { ells }\end{array}$ & $\begin{array}{l}\text { Number } \\
\text { duction } \\
\text { to be drill }\end{array}$ & $\begin{array}{l}\text { of pro- } \\
\text { wells } \\
\text { led }\end{array}$ & $\begin{array}{l}\text { Ratio } \\
\text { tion } y \\
\text { to pro } \\
\text { wells }\end{array}$ & $\begin{array}{l}\text { of injec- } \\
\text { vells } \\
\text { duction }\end{array}$ & $\begin{array}{l}\text { Numb } \\
\text { of inj } \\
\text { wells } \\
\text { drille }\end{array}$ & $\begin{array}{l}\text { ber } \\
\text { ection } \\
\text { to be } \\
\text { d }\end{array}$ \\
\hline 5.33897 & 50 & & 1 & & 4.33897 & & 0.5 & & 2.669 & \\
\hline $\begin{array}{l}\text { Drilling } \\
\text { and associ- } \\
\text { ated costs }\end{array}$ & $\begin{array}{l}\text { Cost multi- } \\
\text { plier }\end{array}$ & & $\begin{array}{l}\text { st per well } \\
\text { SD) }\end{array}$ & $\begin{array}{l}\text { Num } \\
\text { of we }\end{array}$ & $\begin{array}{l}\text { ber } \\
\text { ells }\end{array}$ & $\begin{array}{l}\text { Drillin } \\
\text { (USD) }\end{array}$ & $g$ cost & $\begin{array}{l}\text { Non-drillin } \\
\text { cost (USD) }\end{array}$ & & $\begin{array}{l}\text { Total cost } \\
\text { (USD) }\end{array}$ \\
\hline Exploration & 0.5 & & 0,910 & 2 & & $1,541,8$ & & 750,000 & & $2,291,820$ \\
\hline Confirmation & 1.2 & & 350,183 & 2 & & $3,700,3$ & & 250,000 & & $3,950,367$ \\
\hline Production & Med & & $\$ 41,819$ & 4.338 & & $6,689,9$ & & - & & - \\
\hline Injection & Med & & 541,819 & 2.669 & & $4,115,8$ & & - & & - \\
\hline $\begin{array}{l}\text { Surface } \\
\text { equipment, } \\
\text { installation }\end{array}$ & - & & 5,000 & 8.008 & & - & & $1,001,058$ & & $1,001,058$ \\
\hline $\begin{array}{l}\text { Simulation } \\
\text { cost }\end{array}$ & - & & 000,000 & 8.008 & & - & & $8,008,460$ & & $8,008,460$ \\
\hline $\begin{array}{l}\text { Production } \\
\text { and injection } \\
\text { wells to be } \\
\text { drilled }\end{array}$ & - & - & & 7.008 & & 10,805 & 780 & 250,000 & & $11,055,780$ \\
\hline Gross plant outp & & 357.2 & $283 \mathrm{~kW}$ & & & & & & & \\
\hline Cost & & $0 \$ / k$ & & & & & & & & \\
\hline Power plant cost & & & $108 \$$ & & & & & & & \\
\hline Pump installatio & $\mathrm{n}$ and casing co & & $50 \$ / f t$ & Pun & np depth & 2,859 . & $928 \mathrm{ft}$ & Total cost 1 & 142,9 & $96.4 \$$ \\
\hline Pump cost & & & $12,479.2 \$ / h p$ & Pun & np size & 1345 & 52 hp & Total cost 4 & 457,7 & $71 \$$ \\
\hline Number of pum & ps required & & 5.33897 & Cos & t of pump & 600,7 & & Total cost 3 & 3,207 & $481 \$$ \\
\hline
\end{tabular}

Table 4 Financial model dialog for the geothermal well

\begin{tabular}{|c|c|c|c|c|c|}
\hline \multicolumn{3}{|l|}{ Recapitalization cost } & \multicolumn{3}{|c|}{ Specified recapitalization cost } \\
\hline \multicolumn{3}{|c|}{$\begin{array}{l}\text { Calculated recapitalization cost includes drilling } \\
\text { costs, pump costs, and surface equipment. } \\
\text { When the reservoir temperature drops below } \\
\text { an allowed minimum, new wells must be } \\
\text { drilled and costs accounted for in the out years } \\
\text { of the analysis }\end{array}$} & \multicolumn{3}{|l|}{$23,000,000 \$$} \\
\hline Total capital cost & \multicolumn{3}{|c|}{$71,558,072 \$$} & & \\
\hline Contingency (5\%) & \multicolumn{3}{|c|}{$3,577,904 \$$} & & \\
\hline Total direct cost & \multicolumn{3}{|c|}{$75,135,976 \$$} & & \\
\hline Total installed cost & \multicolumn{3}{|c|}{$92,792,928 \$$} & & \\
\hline Total installed cost per capac & \multicolumn{3}{|c|}{$51,555 \$ / \mathrm{kW}$} & & \\
\hline Indirect capital costs & $\%$ of & direct cost & Non-fixed cost (\$) & Fixed cost & Total cost $(\$)$ \\
\hline Engineer, procure, construct & 16 & & $12,021,756$ & 0 & $12,021,756$ \\
\hline Project, land, miscellaneous & 3.5 & & $2,629,759$ & 0 & $2,629,759$ \\
\hline Sales tax of $5 \%$ applies to & 80 & & - & - & $3,005,439$ \\
\hline \multicolumn{3}{|c|}{ Operation and maintenance cost $\mathrm{Fi}$} & \multicolumn{3}{|c|}{$\begin{array}{l}\text { st Escalation rate (above inflation) } \\
(\%)\end{array}$} \\
\hline \multicolumn{2}{|l|}{ Fixed annual cost } & 0 & \multicolumn{2}{|l|}{0} & \\
\hline \multicolumn{2}{|l|}{ Fixed cost by capacity } & $70 \$ / k W-y r$ & \multicolumn{2}{|l|}{0} & \\
\hline \multicolumn{2}{|l|}{ Variable cost by generation } & $3 \$ / M W h$ & \multicolumn{2}{|l|}{0} & \\
\hline
\end{tabular}




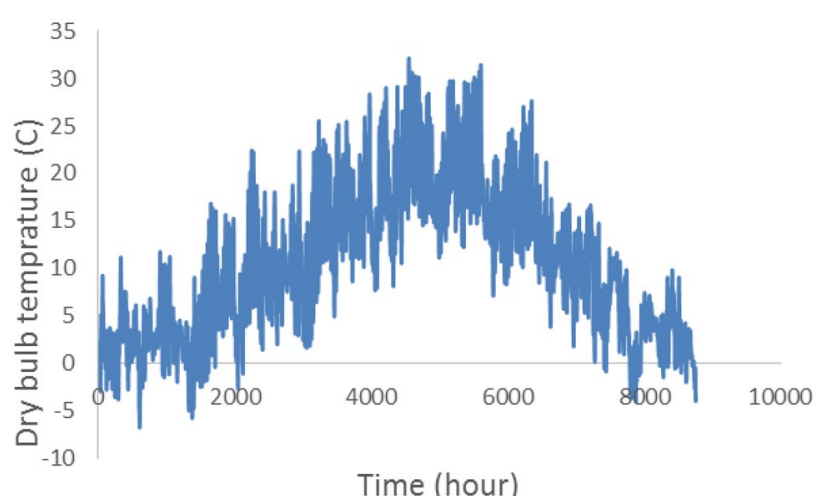

Fig. 4 Recorded dry bulb temperature

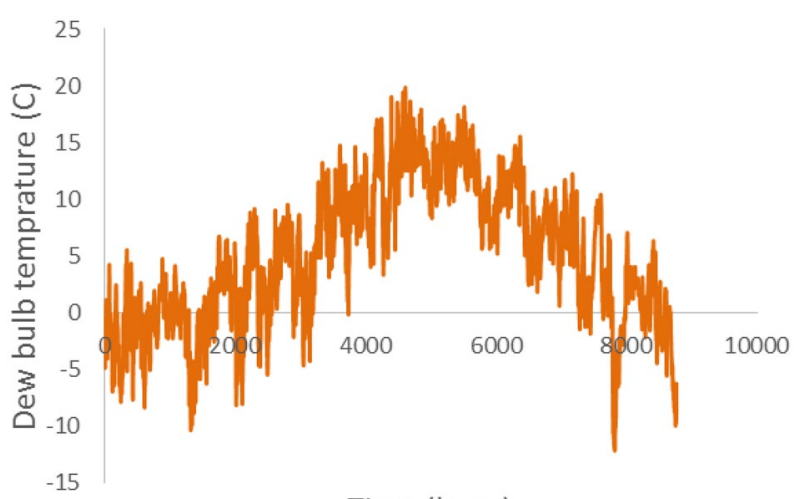

Time (hour)

Fig. 5 Recorded dew point temperature

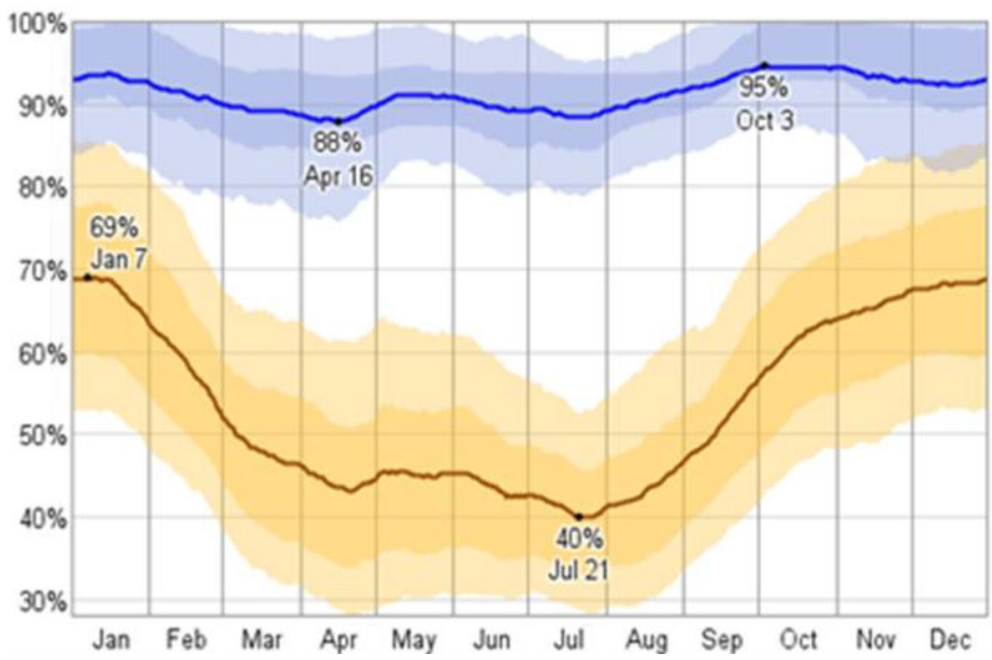

Fig. 6 Recorded annual humidity 


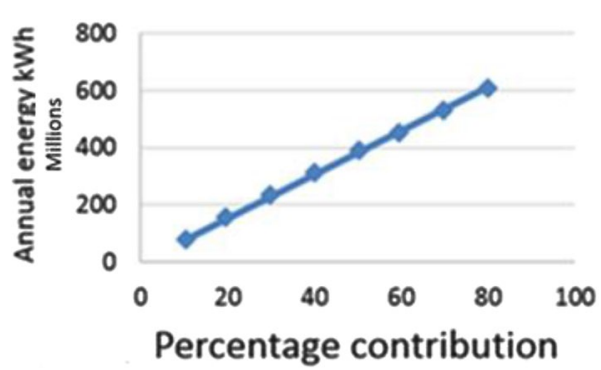

Fig. 7 Annual energy production versus percentage contribution of geothermal energy to the total energy demand

field source limitations. The annual energy in kWh increases linearly with an increase in the percentage of contribution to the total demand. It can also be seen that at $80 \%$ contribution, the annual energy is 465 million $\mathrm{kWh}$.

The power factor shown in Fig. 8 decreases with an increase in the total contribution to the demand, for which there is a decrease from 20 to 7.5 at 10 and $80 \%$ contribution, respectively. However, the power factor remains constant at 7.5 over the 50 to $80 \%$ contribution range.

The heat output is very high at high power outputs, and since it is a single flash power plant, the rest of the heat will not be effectively recycled. Hence, the power factor decreases rapidly with an increase in the power demand. The total cost is very high, reaching 946 million dollars for $80 \%$ contribution as shown in Fig. 9.

For the dual flash power plant, Fig. 10 shows that the annual contribution to the total power demand cannot exceed $80 \%$, which is the same issue faced by the single flash power plant. The annual energy in kWh increases linearly when increasing the percentage of contribution to the total demand. However, at $80 \%$ contribution, the annual energy is 612 million $\mathrm{kWh}$ which is around 32\% higher than that of the single flash power plant.

The power factor in Fig. 11 decreases when increasing the total contribution to the demand with a similar trend as the single flash power plant, for which there is a decrease from 31 to 16.8 at 10 and $80 \%$ contribution, respectively. The power factor is $48 \%$ higher than when using a single flash at $10-20 \%$ contribution, but amazingly it is $124 \%$ higher at $80 \%$ contribution. This is explained by the effective heat recovery and management

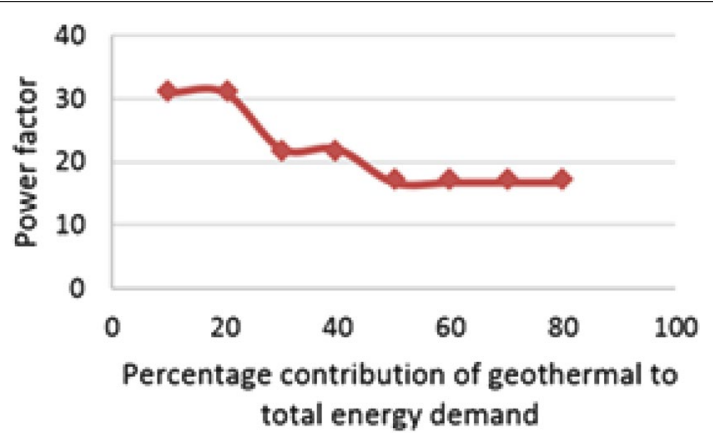

Fig. 8 Power factor versus percentage contribution of geothermal energy to the total energy demand 


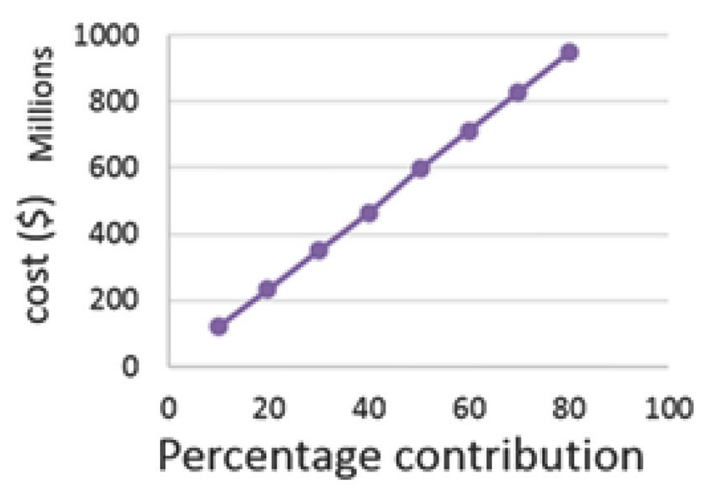

Fig. 9 Cost versus percentage contribution of geothermal energy to the total energy demand

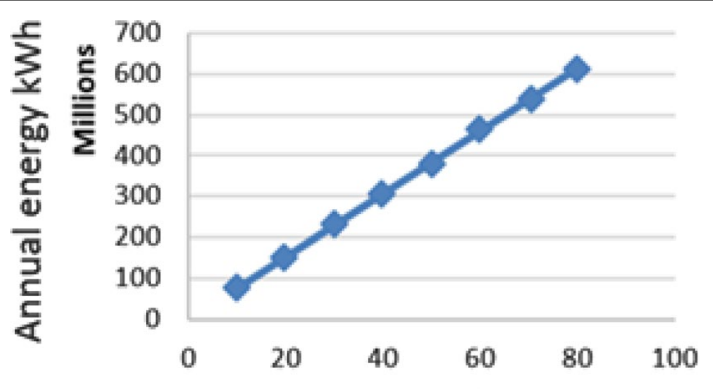

Percentage contribution

Fig. 10 Annual energy production versus percentage contribution of geothermal energy to the total energy demand

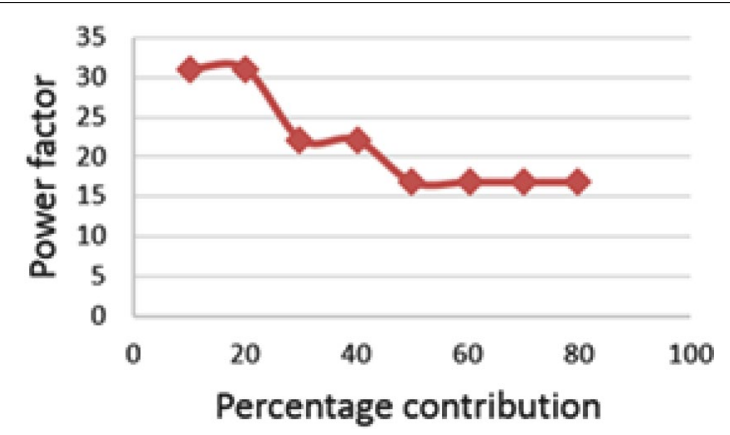

Fig. 11 Power factor versus percentage contribution of geothermal energy to the total energy demand

cycle used in the dual flash power plant. The total cost shown in Fig. 12 is still high, as it reaches 776 million dollars for $80 \%$ contribution. But the total cost is notably lower than for the single flash power plant with a reduction of $18 \%$.

\section{Binary geothermal power plant}

For the binary power plant, Fig. 13 shows that interestingly, the annual contribution to the total power demand can exceed by 80 up to $90 \%$. The annual energy in kWh increases linearly with an increase in the percentage of contribution to the total demand. 


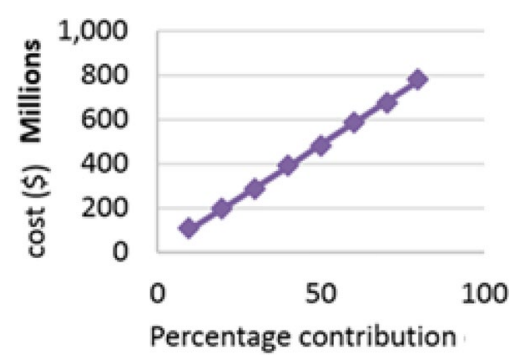

Fig. 12 Cost versus percentage contribution of geothermal energy to the total energy demand

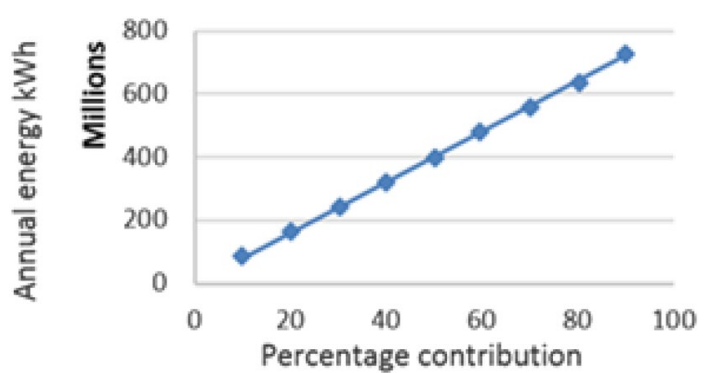

Fig. 13 Annual energy production versus percentage contribution of geothermal energy to the total energy demand

However, at $80 \%$ contribution, the annual energy is 632 million $\mathrm{kWh}$ which is around $36 \%$ higher than when using a single flash power plant and at $90 \%$, the annual energy reaches 711 million $\mathrm{kWh}$ while other power plants fail to produce energy at $90 \%$ contribution Figs. 14, 15.

The power factor in Fig. 16 decreases while the total contribution to the demand is increased. Generally speaking, the power factor is very high compared with single/dual flash power plants. For $10-20 \%$ contribution, the power factor is $36.5 \%$ and drops to $19.6 \%$ at 50 to $90 \%$ contribution. The power factor is higher than that for a single flash by $81 \%$ at 10 to $20 \%$ contribution. But it is $161 \%$ higher at $80 \%$ contribution. The smart system of using secondary fluid provides high system efficiency which effectively allows for better heat management.

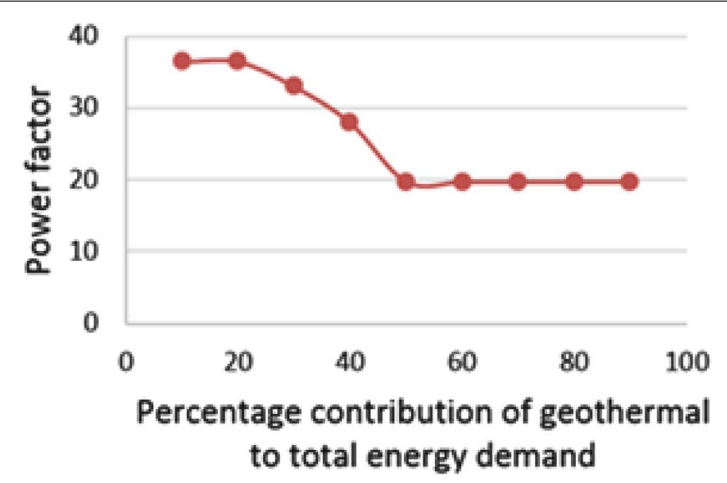

Fig. 14 Power factor versus percentage contribution of geothermal energy to the total energy demand 


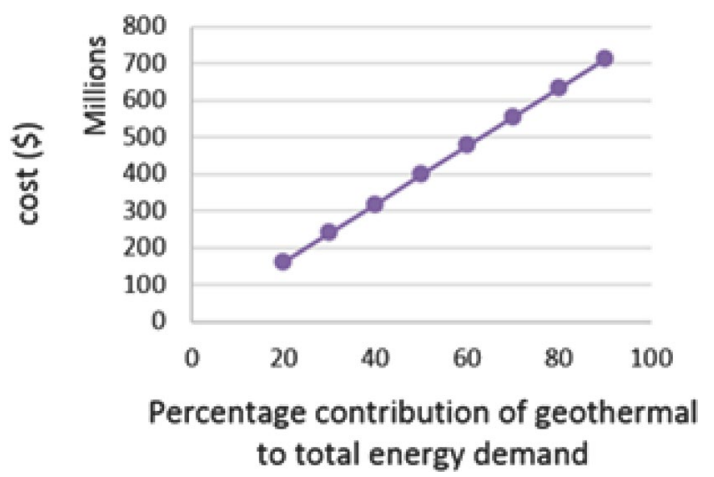

Fig. 15 Cost versus percentage contribution of geothermal energy to the total energy demand

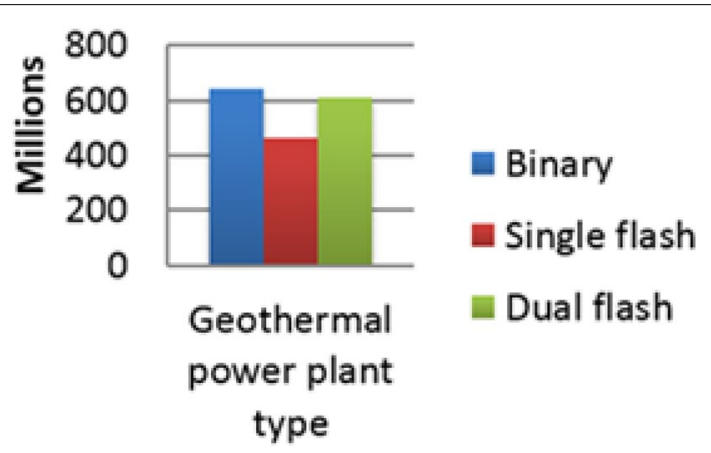

Fig. 16 Annual energy production in $\mathrm{kWh}$ at $80 \%$ contribution for three different power plants

The total cost presented in Fig. 17 is notably lower than that for flash steam power plants at $80 \%$ contribution, the cost is 625 million dollars which corresponds to a $32.2 \%$ reduction in the total cost.

Figures 16, 17, 18 show the great cost reduction that can be attained by using a binary power plant at $80 \%$ geothermal contribution to the total demand. One more advantage is that the binary power plant is the only power plant among the suggested ones able to contribute at $90 \%$ contribution with the available energy source. For the sake of comparison, at $80 \%$ contribution, the annual energy produced by the binary power plant is the highest and the power factor is the highest as well.

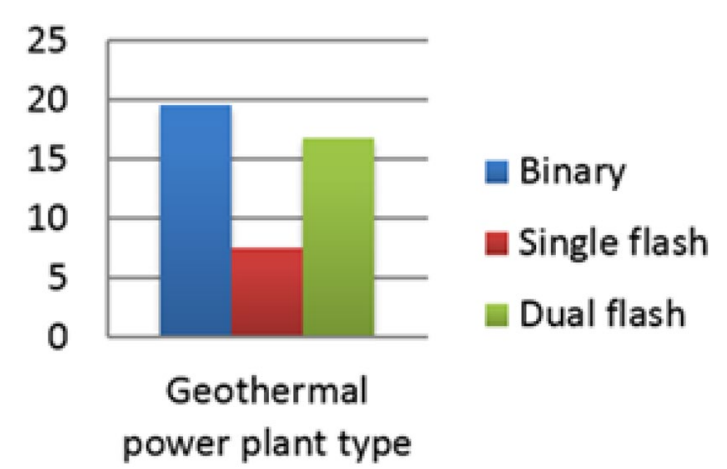

Fig. 17 Power factor at $80 \%$ contribution for three different power plants 


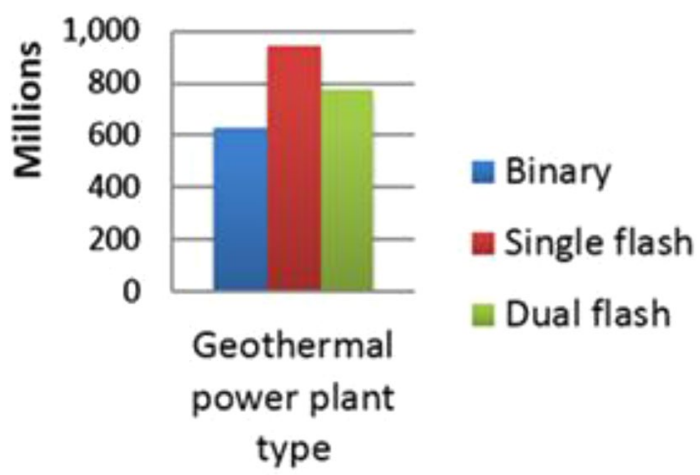

Fig. 18 Cost in US dollars at 80\% contribution for three different power plants

\section{Conclusions}

This work presented a comparative study between three geothermal power plants using SAM. SAM first estimates the electric power production (performance model) and then estimates the energy cost based on a performance model, or more precisely, on a combination of performance and finance models. The comparison is based on the electric power production and energy costs related to the power plant. It can be concluded that the best energy source that can be used in CERN as a renewable energy source with $90 \%$ contribution to the total demand is a binary power plant with a total cost of 625 million USD dollars, an annual energy production of 640,630 MWh, and a power factor of 19.6. The annual energy produced by the binary is the highest and its power factor is the highest as well. This type of geothermal power plant offers a cost reduction of $32.2 \%$ compared to a single flash power plant.

Authors' contributions

Authors agree on the names arrangement given in the manuscript title page. All authors read and approved the final manuscript.

\section{Author details}

1 SREE Department, University of Sharjah, P O Box 27272, Sharjah, United Arab Emirates. ${ }^{2}$ Mechanical Engineering Department, Australian College of Kuwait, P. O. Box 1411, Safat, Kuwait City 13015, Kuwait.

\section{Acknowledgements}

Not applicable.

Competing interests

The authors declare that they have no competing interests.

Availability of data and materials

The data and material presented in this work are available and we used it in our calculations.

Consent of publication

The authors agree to publish this work.

Ethics approval and consent to participate

This work is not published elsewhere nor submitted to another journal.

Funding

Not applicable.

\section{Publisher's Note}

Springer Nature remains neutral with regard to jurisdictional claims in published maps and institutional affiliations. 
References

Ameri M, Shamshirgaran SR, Pour Yousefi M. The study of key thermodynamic parameters effect on the performance of a flash steam geothermal power plant. Proceedings of 2nd Joint International Conference SEE 2006, Bangkok; 2006. Ameri M, Amanpour S. Energy and exergy analysis and optimization of a double flash power plant for Meshkin Shahr region, World Renewable Energy Congress 2011, Sweden 8-13 May 2011, Linköping, Sweden.

Bao J, Zhao L. A review of working fluid and expander selections for organic Rankine cycle. Renew Sustain Energy Rev. 2013;24:325-42.

Dickson MH, Fanelli M. Geothermal energy: utilization and technology. Paris: UNESCO; 2003.

DiPippo R. Geothermal energy as a source of electricity: a worldwide survey of the design and operation of geothermal power plants, U.S. Dept. of Energy, DOE/RA/28320-1. Washington, DC: Gov. Printing Office; 1980.

DiPippo R. Geothermal power plants. 2nd ed. Amsterdam: Elsevier Ltd; 2007.

El Haj Assad M, Bani-Hani E, Sedaghat A, Al-Muhaiteeb A, Khanafer K, Khalil M. New pneumatic system for tidal energy conversion. J Power Energy Eng. 2016;4:20-7.

Garg P, Kumar P, Srinivasan K, Dutta K. Evaluation of isopentane, R-245fa and their mixtures as working fluids for organic Rankine cycles. Appl Therm Eng. 2013;51:292-300.

Gong YL, Luo C, MA WB, WU ZJ. Thermodynamic analysis of geothermal power generation combined flash system with binary cycle, Proceedings World Geothermal Congress, 2010, Bali, Indonesia; 25-29 April; 2010.

Jianyong W, Jiangfeng W, Dai Y. Thermodynamic analysis and comparison of an ORC-OFC combined power generation system, 3rd International Seminar on ORC Power Systems, October 12-14, 2015, Bryssels, Belgium, p. 1-10.

Kagel BA, Bates D, Gawell K. A guide to geothermal energy and environment, Geothermal Energy Association, Technical Report, April; 2007.

Lurque R, Davilla LH, Campelo JM, Clark JH, Hidalgo JM, Luna D. Biofuels: a technological perspective. Energy Environ Sci. 2008;1-5:542-64.

McKendry P. Energy production from biomass (part 1): overview of biomass. Bioresour Technol. 2002;83:37-46.

Negawo W. A Review on the geo material aspects of geothermal reservoirs and its exploration. J Environ Earth Sci. 2016:6:229-38.

Pambudi NA, Itoi R, Jalilinasrabady $S$, Khashani. Performance evaluation of double-flash geothermal power plant at Dieng using second law of thermodynamics, Proceedings, Thirty-Eight Workshop on Geothermal Renewable Engineering, Stanford University: Stanford, California, February 11-13; 2013.

Pazheri FR, Otham MF, Malik NH. A review on global renewable electricity scenario. Renew Sustain Energy Rev. 2014;31:835-45.

Redko A, Kulikova N, Pavlovsky S, Bugai V, Redko O. Efficiency of geothermal power plant cycles with different heatcarriers, Proceedings 41st Workshop on Geothermal Reservoir Engineering, Stanford University: Stanford, California, February 22-24; 2016. p. 1-7.

SAM Help. NREL National Renewable Energy Laboratory. Version 2015.6.30. 2015. https://sam.nrel.gov/.

Sheng Y, Shi X, Zhang D. Economic development, energy market integration and energy demand: Implications for East Asia. Energy Strat Rev. 2013;2(2):146-152.

Teklemariam M, Beyene K, AmdeBerhan Y, Gebregziabher Z. Geothermal development in Ethiopia. Proceedings of World Geothermal Congress. Kyushu-Tohoku, Japan; 2000.

Tester J. The future of geothermal energy, MIT, Technical Report; 2006.

Valdimarsson P. Geothermal power plant cycles and main components, United Nation University, Geothermal training programme organized by UNP-GTP and LaGeo, in Santa Tecla, El Salvador, January 16-22. p. 1-24.

Vuataz RS. Properties of geothermal fluids in Switzerland: a new interactive database. Geothermics. 2008;37:496-509.

Yang K, Zhang H, Wang Z, Zhang J, Yang F, Wang E, Yao B. Study of zeotropic mixtures of ORC (Organic Rankine Cycle) under engine various operating conditions. Energy. 2013;58:494-510.

Yari M. Exergetic analysis of various types of geothermal power plants. Renew Energy. 2010;35:112-21.

Younas $\mathrm{U}$, et al. Pakistan geothermal renewable energy potential for electric power generation: a survey. Renew Sustain Energy Rev. 2016;63:398-413.

\section{Submit your manuscript to a SpringerOpen ${ }^{\circ}$ journal and benefit from:}

- Convenient online submission

- Rigorous peer review

- Open access: articles freely available online

- High visibility within the field

- Retaining the copyright to your article

Submit your next manuscript at $\gg$ springeropen.com 